https://doi.org/10.18778/1509-877X.2021.02.03

\title{
OPODATKOWANIE PODATKIEM OD NIERUCHOMOŚCI URZĄDZEŃ TECHNICZNYCH W POLSCE - ZAGADNiENIA WYBRANE
}

Streszczenie. W artykule przedstawiono przegląd wybranych problemów prawnych, związanych z opodatkowaniem w Polsce podatkiem od nieruchomości urządzeń technicznych stosowanych we współczesnym przemyśle ciężkim i usługowym. Autor koncentruje się na prawie polskim, ale wskazuje także fundamentalne kwestie związane z podatkiem od nieruchomości oraz jego wpływem na politykę fiskalną i podatkową w innych państwach Europy Środkowo-Wschodniej. Szczególną uwagę zwraca na rozróżnienie budynków, budowli i obiektów budowlanych w rozumieniu ustawy o podatkach i opłatach lokalnych oraz Prawa budowlanego. Poruszane są też bardziej złożone zagadnienia, takie jak opodatkowanie sieci elektrycznych i telekomunikacyjnych, elektrofiltrów czy konstrukcji wewnątrz budynków. Ponadto omawia najnowsze poglądy doktryny oraz aktualne stanowiska prezentowane w orzecznictwie sądów administracyjnych.

Słowa kluczowe: podatek od nieruchomości, obiekty budowlane, urządzenia w prawie podatkowym, urządzenia techniczne w przemyśle

* Magister, Uniwersytet Śląski w Katowicach, e-mail: tomasz.gwozdz@us.edu.pl, https://orcid.org/0000-0002-1769-1210 
Na przestrzeni ostatnich lat postęp technologiczny stał się przyczyną licznych wątpliwości praktycznych w zakresie podatku od nieruchomości w Polsce. Zjawisko to spowodowane jest stosowaniem nowoczesnych urządzeń technologicznych, których kwalifikacja i sposób opodatkowania budzą spory pomiędzy podatnikami a organami podatkowymi. Omawiany problem dotyczy przede wszystkim polskiego przemysłu ciężkiego, ale coraz częściej także branż usługowych, w tym telekomunikacji i zaawansowanego sprzętu informatycznego, wykorzystywanego w działalności gospodarczej. Podstawową trudnością jest prawidłowe przyporządkowanie omawianych urządzeń z punktu widzenia podatku od nieruchomości jako budynków, budowli lub obiektów budowlanych - co zapewnić ma z jednej strony należytą dbałość o interes fiskalny jednostek samorządu terytorialnego, a z drugiej zapewnić przestrzeganie konstytucyjnych praw i gwarancji obywateli w dziedzinie opodatkowania, w tym zwłaszcza zasady jasności i określoności prawa podatkowego oraz demokratycznego państwa prawa.

W praktyce orzeczniczej wątpliwości budzi opodatkowanie podatkiem od nieruchomości obiektów budowlanych w kontekście ich kwalifikacji jako budynków lub budowli w rozumieniu Ustawy z dnia 12 stycznia 1991 r. o podatkach i opłatach lokalnych ${ }^{1}$. W opracowaniu kwestia ta zostanie omówiona ze szczególnym uwzględnieniem opodatkowania stacji elektroenergetycznych, sieci telekomunikacyjnych, budowli stworzonych z wykorzystaniem nowoczesnych technologii znajdujących się wewnątrz budynków oraz elektrofiltrów i instalacji odsiarczania spalin.

Co istotne, w większości państw podatek od nieruchomości stanowi ważne źródło dochodów budżetów lokalnych, które następnie są przeznaczane na realizację zadań publicznych. W Polsce decentralizacja w zakresie omawianego podatku oraz przyznane gminom władztwo podatkowe dają im istotne instrumenty prawne, umożliwiające kształtowanie polityki finansowej w tym zakresie, zwłaszcza w odniesieniu do stawek podatku ustalanych w formie uchwały organu stanowiącego jednostki samorządu terytorialnego. Podobnie na Węgrzech oraz na Słowacji widoczna jest samodzielność finansowa jednostek samorządu terytorialnego w tym zakresie, które to kraje, obok Polski, są tu niewątpliwym liderem wśród

1 Tekst jedn. Dz.U. z 2019 r., poz. 1170 ze zm., dalej: u.p.o.l. 
państw Europy Wschodniej². Podatek od nieruchomości pozostaje istotnym elementem w strukturze systemu podatkowego także ze względu na jego stałość i trwałość. W przeciwieństwie do innych rodzajów opodatkowania pozostaje niezmienny w kontekście położenia przedmiotu opodatkowania czy samego faktu istnienia obowiązku podatkowego. Jest więc niezależny od zjawisk globalizacji, umiędzynarodowienia kapitału czy prób agresywnej optymalizacji podatkowej, np. polegających na przenoszeniu siedzib przedsiębiorstw do tzw. rajów podatkowych w celu zmniejszenia opodatkowania podatkiem dochodowym ${ }^{3}$. Nie oznacza to jednak, że w podatku od nieruchomości brak prób dokonywania optymalizacji i zmniejszania wymiaru należności, zwłaszcza przez podmioty prowadzące działalność gospodarczą. Najwięcej wątpliwości i praktycznych problemów budzą obiekty budowlane i urządzenia techniczne, które powstają z wykorzystaniem nowych technologii. Ich dynamiczny rozwój powoduje, że organy podatkowe oraz sądy administracyjne muszą stale dokonywać opartych na zmieniających się stanach faktycznych wykładni obowiązujących przepisów, tym samym wykorzystując w procesie stosowania prawa skomplikowaną, aktualną wiedzę specjalistyczną.

\section{OBIEKTY BUDOWLANE JAKO PRZEDMIOT OPODATKOWANIA}

W PODATKU OD NIERUCHOMOŚCI

Polska ustawa o podatkach i opłatach lokalnych przewiduje opodatkowanie podatkiem od nieruchomości poza gruntami także dwóch rodzajów obiektów budowlanych: budynków i budowli. W praktyce orzeczniczej organów podatkowych i sądów administracyjnych problemy sprawia rozróżnienie pomiędzy nimi, które odgrywa zasadniczą rolę w kontekście wymiaru podatku. W przeciwieństwie do większości państw wysoko rozwiniętych w Polsce podstawą opodatkowania budynków jest bowiem ich powierzchnia użytkowa, a jedynie w odniesieniu do budowli - ich wartość ${ }^{\text {. }}$

2 Zob. P. Felis, H. Rosłaniec, J. Szlęzak-Matusewicz, Property Tax Policy of Rural and Urban-Rural Municipalities in Poland, „Acta Scientiarum Polonorum. Oeconomia” 2019, t. 18, nr 4; A. Vartašová, K. Cervena, The Development of Real Property Tax - the Case of City of Košice, „Financial Law Review” 2020, t. 20, nr 4.

3 Zob. N. Popova, Immovable Property Taxation and Economic Efficiency, „Real Estate Property \& Business" 2020, t. 4, nr 3.

${ }^{4}$ Zob. A. Małkowska, A. Telega, M. Głuszak, B. Marona, Spatial Interdepedence in Property Taxation: The Case of Polish Municipalities, „Equilibrium. Quarterly Journal of Economics and Economic Policy" 2018, t. 13, nr 2. 
Ma to istotne znaczenie w przypadku spornych obiektów budowlanych (zwłaszcza powstałych z wykorzystaniem nowych technologii), które mają niewielką powierzchnię, ale ich wartość jest bardzo wysoka. Ponadto budowle są przedmiotem opodatkowania wyłącznie wtedy, gdy są związane z prowadzeniem działalności gospodarczej.

Definicja legalna budynków i budowli została wprowadzona w art. 1a ust. 1 pkt 1 i 2 u.p.o.l. Zgodnie ze wskazanymi przepisami budynek to obiekt budowlany w rozumieniu przepisów prawa budowlanego, który jest trwale związany z gruntem, wydzielony z przestrzeni za pomocą przegród budowlanych oraz posiada fundamenty i dach. Budowla $z$ kolei to obiekt budowlany w rozumieniu przepisów prawa budowlanego niebędący budynkiem lub obiektem małej architektury, a także urządzenie budowlane w rozumieniu przepisów prawa budowlanego związane z obiektem budowlanym, które zapewnia możliwość użytkowania obiektu zgodnie z jego przeznaczeniem. Obiektem budowlanym w rozumieniu Ustawy z dnia 7 lipca 1994 r. - Prawo budowlane ${ }^{5}$ jest natomiast budynek, budowla bądź obiekt małej architektury, wraz z instalacjami zapewniającymi możliwość użytkowania obiektu zgodnie z jego przeznaczeniem, wzniesiony z użyciem wyrobów budowlanych.

$\mathrm{Na}$ tle przywołanych regulacji wątpliwości budzi rozróżnienie budynku i budowli. Kwestią sporną jest zwłaszcza rozumienie pojęcia trwałego związania z gruntem oraz posiadania fundamentów, które nie zostały precyzyjnie wyjaśnione w przepisach, a ze względu na stale zachodzący postęp technologiczny - w tym w zakresie budownictwa - trudno jednoznacznie je rozstrzygnąć.

W doktrynie i orzecznictwie sądów administracyjnych podkreśla się, że do klasyfikacji obiektu budowlanego jako budynku niezbędne jest spełnienie przez niego łącznie czterech warunków: trwałego związania z gruntem, posiadania fundamentów, wydzielenia z przestrzeni za pomocą przegród budowlanych oraz posiadania dachu. Bez znaczenia - zwłaszcza w odniesieniu do dwóch ostatnich przesłanek - pozostaje stan techniczny takiego budynku, nawet bowiem w sytuacji braku możliwości jego użytkowania zgodnie z przeznaczeniem, stanowi przedmiot opodatkowania aż do ewentualnego zakończenia prac rozbiórkowych obiektu budowlanego - chyba że utraci on wymienione wcześniej cechy budynku6 ${ }^{6}$.

5 Tekst jedn. Dz.U. z 2021 r., poz. 2351 ze zm., dalej: pr. bud.

6 Zob. B. Pahl, Podatki i opłaty lokalne. Teoria i praktyka, LEX/el. 2017; B. Janiak, T. Kosieradzki, R. Piekarz, Opodatkowanie nieruchomości, LEX/el. 2016; wyrok NSA z dnia 16 października 2020 r., sygn. II FSK 1729/18, LEX nr 3090269. 
Doniosłym praktycznie problemem jest także stwierdzenie, czy obiekt budowlany, będący budowlą w rozumieniu art. 3 pkt 3 pr. bud., może być dla celów opodatkowania podatkiem od nieruchomości uznany za budynek w rozumieniu art. 1a ust. 1 pkt 1 u.p.o.l. Wątpliwości w tym zakresie zostały wyjaśnione przez Naczelny Sąd Administracyjny (NSA), który w uchwale z dnia 29 września 2021 r. stwierdził, że jeżeli taki obiekt budowlany spełnia kryteria bycia budynkiem wymienione we wskazanym przepisie, a dodatkowo wyróżnia się cechą posiadania powierzchni użytkowej, o której mowa w art. 4 ust. 1 pkt 2 u.p.o.l., może dla celów podatkowych być uznany za budynek, pomimo jego kwalifikacji jako budowla w rozumieniu Prawa budowlanego ${ }^{7}$.

3. PojęCie trWAŁEgo ZWIĄZANIA Z GRUNTEM I POSIADANIA FUNDAMENTÓW W NAUCE PRAWA PODATKOWEGO I ORZECZNICTWIE POLSKICH SĄDÓW ADMINISTRACYJNYCH

Wymieniona w ustawie o podatkach i opłatach lokalnych przesłanka trwałego związania z gruntem może być rozumiana na różne sposoby. Jednym z nich, prezentowanym przez polskie Ministerstwo Finansów, jest utożsamienie jej z brakiem możliwości odłączenia od gruntu bez uszkodzenia konstrukcji ${ }^{8}$. Każdy obiekt budowlany mający fundamenty byłby więc zgodnie $\mathrm{z}$ tym rozumieniem uznany za trwale związany z gruntem, i to bez względu na inne okoliczności. Najważniejszy pozostaje w tej interpretacji jego fizyczny związek z gruntem poprzez fundamenty. W orzecznictwie sądów administracyjnych dostrzegalne są z kolei dwa inne sposoby wykładni pojęcia trwałego związania obiektu budowlanego z gruntem. Pierwszy z nich wiąże omawianą przesłankę z brakiem możliwości przeniesienia obiektu budowlanego w inne miejsce bez jego uszkodzenia9 ${ }^{9}$. Drugi z kolei

7 Zob. uchwała NSA z dnia 29 września 2021 r., sygn. III FPS 1/21, LEX nr 3230106.

8 Zob. pismo Ministerstwa Finansów z dnia 10 lutego 2003 r., nr LK-2443/LP/02/AP, LEX/el.

9 Zob. wyroki NSA: z dnia 27 listopada 2018 r., sygn. II FSK 3118/16, LEX nr 2587078; z dnia 9 stycznia 2018 r., sygn. II FSK 3411/15, LEX nr 2427404; z dnia 5 grudnia 2017 r., sygn. II FSK 3236/15, LEX nr 2419303; z dnia 21 listopada 2017 r., sygn. II FSK 2956/15, LEX nr 2422886. Inny pogląd wyraził Naczelny Sąd Administracyjny w wyrokach: z dnia 7 sierpnia 2018 r., sygn. II FSK 1983/16, LEX nr 2532545, oraz z dnia 20 czerwca 2008 r., sygn. II OSK 680/07, LEX nr 485005, w których stwierdzono, że okoliczność montowania obiektu budowlanego $\mathrm{z}$ elementów gotowych, które mogą być rozmontowane i przeniesione $\mathrm{w}$ inne miejsce, nie ma istotnego znaczenia dla uznania go za trwale związany z gruntem. 
za decydującą uznaje technologię wykonania obiektu budowlanego. Sposób związania $\mathrm{z}$ gruntem ma w tym rozumieniu pozwalać na przeciwstawienie się czynnikom atmosferycznym, które nie mogą powodować przesunięcia czy przewrócenia obiektu budowlanego ${ }^{10}$. Ten ostatni pogląd budzi jednak wiele wątpliwości w literaturze przedmiotu, pojawiają się bowiem zarzuty, że nie oddaje on istoty spornego zagadnienia w kontekście opodatkowania obiektów budowlanych ${ }^{11}$.

Ponadto podkreślenia wymaga, że zawarte w art. 1 a ust. 1 pkt 1 u.p.o.l. oraz $\mathrm{w}$ art. 3 pkt 2 pr. bud. pojęcie trwałego związania $\mathrm{z}$ gruntem powinno być rozumiane w ujęciu językowym, a nie w znaczeniu, o jakim mowa w art. $47 \$ 2$ i 3 w zw. z art. 48 Ustawy z dnia 23 kwietnia 1960 r. - Kodeks cywilny $^{12}$. W związku z powyższym okoliczności, czy budynek jest częścią składową gruntu, a także czy jego właściciel jest dzierżawcą nieruchomości gruntowej na niej położonej, nie mają znaczenia dla stwierdzenia, co jest przedmiotem opodatkowania ${ }^{13}$. Za takim poglądem przemawia też fakt, że w art. 2 u.p.o.l. ustawodawca nie posłużył się wyłącznie pojęciem nieruchomość, ale objął zakresem przedmiotowym również obiekty budowlane, które do nich nie będą zaliczane. Także definicja legalna budynku, znajdująca się w art. 1a ust. 1 pkt 1 u.p.o.l., posługuje się pojęciem obiektu budowlanego, a nie np. nieruchomości budynkowych. Podsumowując, za niewłaściwe należy uznać tłumaczenie cechy trwałego związania z gruntem w ujęciu cywilistycznym, ponieważ na gruncie podatku od nieruchomości ogranicza się ona do posadowienia obiektu budowlanego na tyle trwałego, by zapewnić mu stabilność i możliwość przeciwdziałania czynnikom zewnętrznym, które mogłyby zmienić lub przemieścić go w inne miejsce ${ }^{14}$.

Kolejnym istotnym elementem rozstrzygającym o sposobie opodatkowania obiektów budowlanych jest kwestia posiadania fundamentów. Ustawa o podatkach i opłatach lokalnych, podobnie jak Prawo budowlane,

10 Zob. wyroki NSA: z dnia 26 września 2018 r., sygn. II FSK 2773/16, LEX nr 2578602, oraz z dnia 29 lipca 2010 r., sygn. II OSK 1234/09, LEX nr 694433.

11 Zob. R. Dowgier, L. Etel, G. Liszewski, B. Pahl, Ustawa o podatkach i opłatach lokalnych. Komentarz, LEX/el. 2020; P. Borszowski, K. Stelmaszczyk, Ustawa o podatkach i opłatach lokalnych. Komentarz, LEX/el. 2016; Ustawa o podatkach i opłatach lokalnych. Komentarz, red. W. Modzelewski, Legalis/el. 2021.

12 Tekst jedn. Dz.U. z 2020 r., poz. 1740 ze zm.

13 Zob. wyrok NSA z dnia 6 kwietnia 2017 r., sygn. II FSK 630/15, LEX nr 2289765.

14 Zob. S. Babiarz, Trwałe związanie z gruntem oraz fundamenty jako elementy definicji budynku w ustawie o podatkach i opłatach lokalnych, „Przegląd Podatków Lokalnych i Finansów Samorządowych" 2018, nr 3(205), s. 18-19. 
nie wyjaśniają jednak znaczenia tego pojęcia. Ministerstwo Finansów i Ministerstwo Infrastruktury zaproponowały pogląd, że fundamentem jest element konstrukcji budowlanej, w jej najniższej części, mający za zadanie przekazanie ciężaru budowli na grunt, np. ława, stopa fundamentowa. Może on przy tym zostać wykonany z różnych materiałów, takich jak drewno, beton czy kamień, a także z wykorzystaniem różnego rodzaju technologii: murowanych, prefabrykowanych, monolitycznych czy płytowych ${ }^{15}$.

W razie wątpliwości co do trwałości związania obiektu budowlanego z gruntem lub posiadania fundamentów konieczne jest przeprowadzenie $\mathrm{w}$ ramach postępowania podatkowego dowodu $\mathrm{z}$ opinii biegłego, posiadającego specjalistyczną wiedzę w tym zakresie. Mogą się one pojawić między innymi w sytuacji, gdy fundament lub jego elementy nie są widoczne lub są wykonane $\mathrm{z}$ wykorzystaniem nowoczesnych technologii, a podatnik neguje ich istnienie ${ }^{16}$.

\section{Nowe TeChNOLOGIE WYKORZYSTYWANE W OBIEKTACH BUDOWLANYCH}

A PODATEK OD NIERUCHOMOŚCI

Na gruncie omówionych dotychczas zagadnień pojawiły się praktyczne problemy orzecznicze dotyczące rozróżnienia budynku oraz budowli w rozumieniu ustawy o podatkach i opłatach lokalnych, a także określenia przedmiotu opodatkowania w tym zakresie. Wynikały one głównie ze stosowanych nowoczesnych rozwiązań technologicznych, w odniesieniu do których nie zostały przewidziane odpowiednie regulacje prawne wprost rozstrzygające o ich statusie na potrzeby prawa podatkowego.

Pierwszym omówionym w niniejszym artykule spornym zagadnieniem jest kwestia opodatkowania stacji elektroenergetycznych, które mogą się składać m.in. $z$ rozdzielni prądu, autotransformatorów, agregatów prądotwórczych czy baterii akumulatorów. Wątpliwości budzi tutaj z jednej strony możliwość zakwalifikowania ich jako budowli - w sytuacji gdy spełniają definicję budynku

15 Zob. L. Etel, Ustawa o podatkach $i$ opłatach lokalnych. Komentarz, LEX/el. 2012; pismo Ministerstwa Finansów z dnia 29 listopada 2004 r., nr LK-741/LP/PP/04, LEX/el.; M. Binaś, Podatek od nieruchomości - ujęcie praktyczne, Legalis/el. 2019; wyrok NSA z dnia 14 października 2020 r., sygn. II FSK 1824/18, LEX nr 3104151; wyrok WSA w Gliwicach z dnia 12 lutego 2021 r., sygn. I SA/Gl 882/20, LEX nr 3122845.

16 Zob. L. Etel, Opinia biegłego a ekspertyza prawna w postepowaniu podatkowym, http://www.eksperci.uwb.edu.pl/wp-content/uploads/2011/02/opinia_bieglego.pdf (dostęp: 25.04.2021). 
wyrażoną w ustawie o podatkach i opłatach lokalnych, a z drugiej strony wykładnia przesłanki zawartej w definicji legalnej, na mocy której budowlą jest także urządzenie budowlane związane z obiektem budowlanym, które zapewnia możliwość użytkowania obiektu zgodnie z przeznaczeniem.

Kwestia kwalifikacji jako budowli obiektów budowlanych spełniających warunki budynku była przedmiotem analizy Trybunału Konstytucyjnego (TK). Stoi on na stanowisku ${ }^{17}$, że uznanie obiektu budowlanego - spełniającego wymogi budynku z art. 1a ust. 1 pkt 1 u.p.o.l. - za budowlę jest niezgodne $\mathrm{z}$ zasadą szczególnej określoności regulacji daninowych, która została wywiedziona z treści art. 84 w zw. z art. 217 i art. 64 ust. 3 Konstytucji Rzeczypospolitej. Uzasadniając rozstrzygnięcie, Trybunał stwierdził, że brzmienie przepisu definiującego budynek i budowlę jest na tyle jednoznaczne, że nie może zostać podważone poprzez dokonanie wykładni celowościowej, zwłaszcza na niekorzyść podatnika. Wynika z niego, że żaden budynek nie może być jednocześnie budowlą, a budowla budynkiem - przy czym pierwszeństwo (pod warunkiem posiadania cech wynikających z przepisów) przysługuje kwalifikacji jako budynku ${ }^{18}$. Pomimo krytyki ze strony niektórych przedstawicieli nauki prawa podatkowego ${ }^{19}$ stanowisko zostało zaaprobowane również w orzecznictwie sądów administracyjnych ${ }^{20}$.

Pokreślenia wymaga jednak, że wynikający z omawianego wyroku TK zakaz kwalifikacji obiektów budowlanych jednocześnie jako budynku i budowli nie wyklucza uznania za budowlę obiektów budowlanych, które nie odpowiadają definicji budynku, nawet jeżeli znajdują się one wewnątrz budynku' ${ }^{21}$.

17 Zob. wyrok TK z dnia 13 grudnia 2017 r., sygn. SK 48/15, OTK-A 2018/2.

18 Zob. R. Dowgier, Budynek czy budowla? Kilka uwag na tle wyroku TKz 13.12.2017 r., SK 48/15, „Przegląd Podatków Lokalnych i Finansów Samorządowych” 2018, nr 4(206); S. Czarnecki, The Principles of Determining Real Estate Tax in the Light of the Latest Judgments of the Constitutional Tribunal, „WSEI Scientific Journal series: ECONOMICS” 2017, t. 1-2(13-14), s. 77-79; P. Banasik, Podatki i opłaty lokalne. Podatek leśny. Podatek rolny, Warszawa 2019, s. 23.

19 Por. K. Radzikowski, Opodatkowanie podatkiem od nieruchomości „,budowli w budynku” w świetle wyroku Trybunału Konstytucyjnego w sprawie SK 48/15, „Zeszyty Naukowe Sądownictwa Administracyjnego" 2018, nr 5(80), LEX/el.

20 Zob. wyroki NSA: z dnia 14 maja 2019 r., sygn. II FSK 1563/17, LEX nr 2675702; z dnia 14 maja 2019 r., sygn. II FSK 1599/17, LEX nr 2676618; z dnia 22 lipca 2020 r., sygn. II FSK 1011/20, LEX nr 3058591.

${ }^{21}$ Zob. wyrok NSA z dnia 24 listopada 2020 r., sygn. II FSK 1317/20, LEX nr 3106525; wyrok Wojewódzkiego Sądu Administracyjnego (WSA) w Bydgoszczy z dnia 15 grudnia 
Druga sporna kwestia dotyczy interpretacji określenia budowli jako urządzenia budowlanego $\mathrm{w}$ rozumieniu przepisów prawa budowlanego związanej z obiektem budowlanym, która zapewnia możliwość użytkowania go zgodnie z przeznaczeniem. Zgodnie z art. 3 pkt 9 pr. bud. zaliczyć do nich należy m.in. przyłącza i urządzenia instalacyjne, w tym służące oczyszczaniu lub gromadzeniu ścieków, a także przejazdy, ogrodzenia, place postojowe i place pod śmietniki. Bez znaczenia pozostaje przy tym, czy obiekt budowlany jest wznoszony od podstaw w miejscu jego przeznaczenia, czy też jest już w kompletnej postaci montowany. Konsekwencją takiego rozwiązania jest objęcie podatkiem od nieruchomości także obiektów i urządzeń będących elementami ciągu technologicznego - bez względu na to, czy zostaną zakwalifikowane jako obiekty budowlane czy jako urządzenia budowlane ${ }^{22}$.

Kolejnym problemem praktycznym, dotyczącym przede wszystkim opodatkowania podatkiem od nieruchomości elementów sieci telekomunikacyjnej czy elektroenergetycznej, jest klasyfikacja zawartej w niej kanalizacji kablowej oraz zainstalowanych kabli. W aktualnym brzmieniu ustawy Prawo budowlane znalazł się przepis, na mocy którego kanalizacja kablowa stanowi obiekt liniowy, będący szczególnym rodzajem obiektu budowlanego, natomiast kable zainstalowane w kanalizacji kablowej, kanale technologicznym oraz telekomunikacyjne dowieszone do już istniejącej linii kablowej nadziemnej - nie stanowią obiektu budowlanego lub jego części ani urządzenia budowlanego. Prowadzi to do wniosku, że kanalizacja kablowa, w której znajduje się linia telekomunikacyjna, stanowi obiekt budowlany (konkretnie: obiekt liniowy), a w związku z tym jest budowlą ${ }^{23}$. Należy zauważyć, że tak ukształtowany przepis został dodany do polskiego porządku prawnego w 2010 r. Ustawą z dnia 7 maja 2010 r. o wspieraniu rozwoju usług i sieci telekomunikacyjnych ${ }^{24}$. Nastąpiło to po wielu sporach pomiędzy podatnikami a organami podatkowymi, dotyczących kwestii opodatkowania kanalizacji kablowej i wypełniających ją kabli jako jednej

2020 r., sygn. I SA/Bd 728/20, LEX nr 3109174; R. Dowgier, L. Etel, G. Liszewski, B. Pahl, Ustawa o podatkach...

22 Zob. R. Dowgier, L. Etel, G. Liszewski, B. Pahl, Ustawa o podatkach...

${ }_{23}$ Zob. A. Despot-Mładanowicz, Komentarz do art. 3, [w:] Prawo budowlane. Komentarz, red. A. Plucińska-Filipowicz, M. Wierzbowski, LEX/el. 2021; W. Piątek, do art. 3, [w:] Prawo budowlane. Komentarz, red. A. Gliniecki, LEX/el. 2016.

24 Dz.U. z 2010 r., Nr 106, poz. 675. 
całości techniczno-użytkowej, a tym samym jednej budowli - w zakresie kontenerów telekomunikacyjnych lub elektroenergetycznych ${ }^{25}$.

W orzecznictwie sądów administracyjnych podkreśla się także, że kontenerowa stacja transformatorowa powiązana $\mathrm{z}$ istniejącą siecią elektroenergetyczną i nowymi liniami kablowymi, które mają na celu przyłączenie nowych odbiorców energii elektrycznej, powinna być uznana za element linii elektroenergetycznej, stanowiącej element budowli ${ }^{26}$. Ponadto, nawet jeżeli dojdzie do rozdzielenia własności poszczególnych elementów budowli na różne podmioty, w dalszym ciągu pozostaje ona jedną techniczną całością (sieć telekomunikacyjna) i tym samym przedmiotem podatku od nieruchomości jako budowla ${ }^{27}$.

Innym przykładem trudności z określeniem przedmiotu opodatkowania w podatku od nieruchomości w związku z zastosowaniem nowoczesnych rozwiązań technologicznych, są elektrofiltry oraz instalacje odsiarczania spalin jako specyficzne urządzenia techniczne. Służą one do usuwania pyłów, dymów czy spalin z powietrza za pomocą siły elektrostatycznej. Elektrofiltr jest na ogół wsparty na konstrukcji nośnej, nazywanej częścią budowlaną. Nie ulega więc wątpliwości, że jest to urządzenie techniczne posiadające części budowlane - i to właśnie one najczęściej stanowią budowlę - o ile nie spełniają ustawowych warunków do opodatkowania ich jako budynki. Sam elektrofiltr nie jest jednak przedmiotem podatku od nieruchomości ${ }^{28}$. Na marginesie należy zaznaczyć, że w starszym orzecznictwie sądów administracyjnych elektrofiltry w całości bywały uznawane za samodzielne budowle. Opodatkowaniu w takiej sytuacji podlegały więc zarówno elementy budowlane, jak i pozostała część techniczna elektrofiltru ${ }^{29}$.

25 Zob. wyroki NSA: z dnia 15 stycznia 2019 r., sygn. II FSK 25/17, LEX nr 2619454; z dnia 17 stycznia 2019 r., sygn. II FSK 309/17, LEX nr 2615353; z dnia 9 stycznia 2019 r., sygn. II FSK 3596/16, LEX nr 2614891; z dnia 1 sierpnia 2019 r., sygn. II FSK 443/19, LEX nr 2706415.

26 Zob. wyrok WSA w Rzeszowie z dnia 5 marca 2019 r., sygn. II SA/Rz 55/19, LEX nr 2645822.

27 Zob. wyrok NSA z dnia 9 stycznia 2019 r., sygn. II FSK 2/17, LEX nr 2616697.

28 Zob. P. Banasik, Opodatkowanie podatkiem od nieruchomości urządzeń technicznych na przykładzie elektrofiltrów, „Przegląd Podatkowy” 2019, nr 10, LEX/el.; wyrok NSA z dnia 31 stycznia 2019 r., sygn. II FSK 123/17, LEX nr 2627775; wyrok WSA w Gliwicach z dnia 21 listopada 2018 r., sygn. I SA/Gl 969/18, LEX nr 2588065.

29 Zob. wyroki NSA: z dnia 9 kwietnia 2013 r., sygn. II FSK 3004/11, LEX nr 1310443; z dnia 9 kwietnia 2013 r., sygn. II FSK 3013/11, LEX nr 1337006. 
5. WNIOSKI

Podsumowując, polskie przepisy dotyczące podatku od nieruchomości są skomplikowane i coraz trudniejsze do zastosowania, zwłaszcza biorąc pod uwagę stanowiące jego przedmiot urządzenia technologiczne. Stosowanie nowoczesnych technologii w tym zakresie może bowiem umożliwiać stworzenie obiektu budowlanego, który spełniając cechy budynku, wymienione $\mathrm{w}$ ustawie, będzie mógł zostać przeniesiony $\mathrm{w}$ inne miejsce bez uszczerbku dla jego konstrukcji i możliwości użytkowania zgodnie z przeznaczeniem. Podobnie sposób związania obiektu z gruntem i posiadania fundamentów wobec nowych technologii stosowanych w branży budowlanej nie jest już jednoznaczny w ocenie ${ }^{30}$. Wymagana jest w tym zakresie aktualna wiedza specjalistyczna, umożliwiająca rozstrzygnięcie spornych kwestii. Stąd rosnąca rola w prowadzonych przez organy postępowaniach podatkowych dowodów z opinii biegłych, gdyż niejednokrotnie jest to jedyny sposób obiektywnej oceny spełniania przez obiekt budowlany przesłanek zawartych w definicji budynku lub budowli.

Zdaniem autora przepisy regulujące opodatkowanie obiektów budowlanych podatkiem od nieruchomości w Polsce powinny zostać znacząco zmodyfikowane, ponieważ nie odpowiadają zmianom zachodzącym w przemyśle ciężkim, budownictwie i nowoczesnym sprzęcie, wykorzystywanym w branżach usługowych. Enumeratywne wyliczenie urządzeń technicznych i metod konstrukcyjnych wykorzystywanych do tworzenia obiektów budowlanych klasyfikowanych jako budynki lub budowle wydaje się niemożliwe. Obecne rozwiązania nie zapewniają należnych, stabilnych dochodów budżetów jednostek samorządu terytorialnego i podtrzymują niepewność podatników co do ich zobowiązań z tytułu podatku od nieruchomości, co należy ocenić w sposób jednoznacznie negatywny.

\section{BIBLIOGRAFIA}

Babiarz S., Trwałe zwiazanie z gruntem oraz fundamenty jako elementy definicji budynku $w$ ustawie o podatkach i opłatach lokalnych, „Przegląd Podatków Lokalnych i Finansów Samorządowych" 2018, nr 3(205).

Banasik P., Opodatkowanie podatkiem od nieruchomości urzadzeń technicznych na przykładzie elektrofiltrów, „Przegląd Podatkowy” 2019, nr 10.

Banasik P., Podatki i opłaty lokalne. Podatek leśny. Podatek rolny, Warszawa 2019.

30 Zob. wyroki NSA: z dnia 13 marca 2019 r., sygn. II FSK 1010/17, LEX nr 3066189; z dnia 20 marca 2015 r., sygn. II FSK 586/13, LEX nr 1774469. 
Binaś M., Podatek od nieruchomości - ujęcie praktyczne, Legalis/el. 2019.

Borszowski P., Stelmaszczyk K., Ustawa o podatkach i opłatach lokalnych. Komentarz, LEX/el. 2016.

Czarnecki S., The Principles of Determining Real Estate Tax in the Light of the Latest Judgments of the Constitutional Tribunal, „WSEI Scientific Journal series: ECONOMICS” 2017.

Dowgier R., Budynek czy budowla? Kilka uwag na tle wyroku TK z 13.12.2017., SK 48/15, „Przegląd Podatków Lokalnych i Finansów Samorządowych” 2018, nr 4(206).

Dowgier R., Etel L., Liszewski G., Pahl B., Ustawa o podatkach i opłatach lokalnych. Komentarz, LEX/el. 2020.

Etel L., Ustawa o podatkach i opłatach lokalnych. Komentarz, LEX/el. 2012.

Felis P., Rosłaniec H., Szlęzak-Matusewicz J., Real Estate Tax Policy of Rural and UrbanRural Municipalities in Poland, „Acta Scientiarum Polonorum. Oeconomia” 2019, nr 18(4), https://doi.org/10.22630/ASPE.2019.18.4.42

Głuszak M., Małkowska A., Marona B., Telega A., Spatial Interdependence in Real Estate Taxation: The Case of Polish Municipalities, „Equilibrium. Quarterly Journal of Economics and Economic Policy" 2018, nr 13(2), https://doi.org/10.24136/eq.2018.014 Janiak B., Kosieradzki T., Piekarz R., Opodatkowanie nieruchomości, LEX/el. 2016. Pahl B., Podatki i opłaty lokalne. Teoria i praktyka, LEX/el. 2017.

Popova N., Immovable Real Estate Taxation and Economic Efficiency, „Real Estate \& Business" 2020, nr 4(3).

Prawo budowlane. Komentarz, red. A. Gliniecki, LEX/el. 2016.

Prawo budowlane. Komentarz, red. A. Plucińska-Filipowicz, M. Wierzbowski, LEX/el. 2021.

Radzikowski K., Opodatkowanie podatkiem od nieruchomości „budowli w budynku” w świetle wyroku Trybunału Konstytucyjnego w sprawie SK 48/15, „Zeszyty Naukowe Sądownictwa Administracyjnego" 2018, nr 5(80).

Ustawa o podatkach i opłatach lokalnych. Komentarz, red. W. Modzelewski, Legalis/el. 2021.

Vartašová A., Cervena K., The Development of Real Estate Tax - the Case of the City of Košice, „Financial Law Review” 2020, nr 20(4), https://doi.org/10.4467/22996834 FLR.20.022.13094

\section{LEGAL REVIEW OF SELECTED ISSUES OF TAXATION WITH REAL ESTATE TAX in Poland of Different technical deVices}

Summary. The study provides a high-level law technical walk-through of selected problems of taxation with real estate tax in Poland, especially connected with technological devices used in modern heavy industry and service industry. It focuses on Polish law and points out the fundamental issues related to real estate tax and its influence on fiscal and taxation politics in other Central and Eastern European countries. In the article particular attention is paid to the distinction of the buildings, structures, and building objects within the meaning of the act on local taxes and fees and the Construction Law. Then, more complex issues are discussed, such as taxation of electricity and telecommunication networks, electrostatic precipitators, and structures inside buildings. The latest views of the doctrine and current positions presented in the jurisprudence of administrative courts are analyzed hereinbelow.

Keywords: real estate tax in Poland, construction objects, technology in tax law, technical devices in heavy industry 